\title{
《解 説》
}

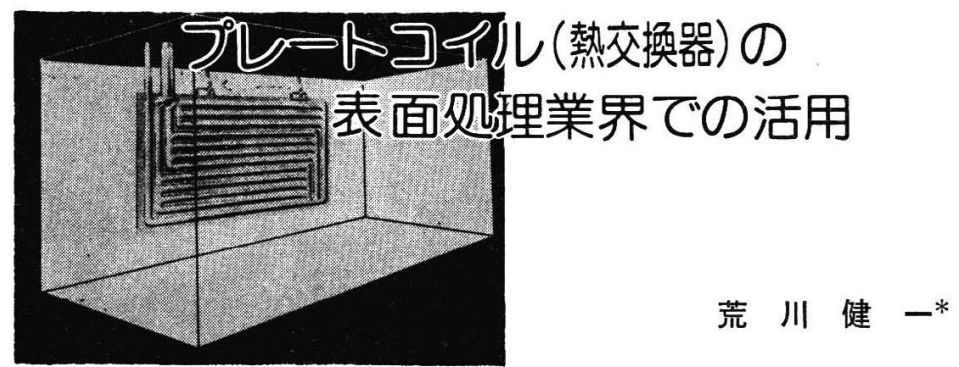

カットプレートコイル

\section{最近, 急激に使用されてきた板状熱交換器 （プレートコイル）の特徵とその利用法, 並 びに従来の熱交換との効率比較データをもと にエネルギー節減について述べる。}

\section{1.はじめに}

従来，加熱又は冷却用蛇管には既製品がな く，必要の都度設計，製作するため多くの労 カを要していました。プレートコイルはエン ボスの板材を特殊溶接し, 熱効率を飛躍的に 向上させた板状の熱交換器で, 現在我が国で は, 大小含め既に約 6 千枚以上のプレートュ イルが表面処理業界は勿論, あらゆる業界に 使用され熱勃率の良さで用途は年々増加して いをす（図1カット参照)。

\section{2. プレートコイルの主な特長}

プレートコイルの特長は以下のようです。

(1) 従来の蛇管にくらべ重量は約 $1 / 2$

軽量で占積率にすぐれ，かつ持ち運びが 容易で, 取付け, 保守にホイストは不要。

(2) タンクに取付けが簡単

内容物をタンクより出さないで自由に取

*あらかわ けんいち 日本パーカライジング(株), プレートコイル部長（テ103）東京都央中区日本橋216-18 電話03 (275) 1049
りはずしができる。

(3) タンクの実稼動容量の増加 例兑ば， $22^{\prime \prime}$ 幅 $\times 47 "$ 長さのプレートコイ

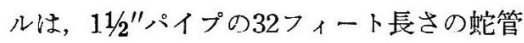
熱交換器 $30^{\prime \prime} \times 60^{\prime \prime}$ 亿相当します。

(4) 清掃が容易

スケール，付着物が従来の蛇管より簡単 に除去できます。

(5) 丈夫な構造

熱交換と同時に, 壁, 仕切り, バッフル に兼用でき，またプレートユイルで容器も 作れます。

\section{3. プレートコイルの枋質}

現在，標準品として一般に市販しているる のは, 軟鋼, SUS 304, SUS 316の 3 種類で,

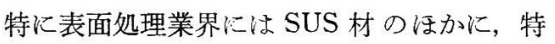
殊仕様として，八ステロイB， 八ステロイC -276 , カーペンター $-20-\mathrm{Cb}-3$, チタン, そ して,グラスライニング拉よびテフロンュー ティングのプレートコイルなどを製作してい ます。 
表 1 プレートコイル常用使用圧力

\begin{tabular}{|c|c|c|c|}
\hline \multicolumn{2}{|l|}{ 厚 } & \multirow{2}{*}{ 軟鋼 $\left(\mathrm{kg} / \mathrm{cm}^{2}\right)$} & \multirow{2}{*}{$\begin{array}{c}\text { ステンレス } \\
304 \cdot 304 \mathrm{~L} \\
316 \cdot 316 \mathrm{~L} \\
\text { モネル }\left(\mathrm{kg} / \mathrm{cm}^{2}\right)\end{array}$} \\
\hline \multicolumn{2}{|c|}{ ダブルコイル } & & \\
\hline \multicolumn{2}{|c|}{$1.6 \mathrm{~m} / \mathrm{m}$} & 6.0 & 7.0 \\
\hline \multicolumn{2}{|c|}{$2.0 \mathrm{~m} / \mathrm{m}$} & 10.0 & 11.0 \\
\hline \multicolumn{2}{|c|}{$2.3 \mathrm{~m} / \mathrm{m}$} & 13.0 & 13.0 \\
\hline \multicolumn{2}{|c|}{ シングルコイル } & \multirow[b]{2}{*}{$\left(\mathrm{kg} / \mathrm{cm}^{2}\right)$} & \multirow[b]{2}{*}{$\left(\mathrm{kg} / \mathrm{cm}^{2}\right)$} \\
\hline エンボス & フラット & & \\
\hline 1.6 & 1.6 & 4.0 & 5.0 \\
\hline 2.0 & 2.0 & 6.0 & 8.0 \\
\hline 2.3 & 3.2 & 8.0 & 10.0 \\
\hline
\end{tabular}

\section{4. プレートコイルの板厚と常用圧力}

プレートコイルは使用圧力(熱媒, 冷媒)に 応じて板厚を選定しますが，標準品として， 軟鋼では $1.6 \mathrm{~mm} 2.3 \mathrm{~mm} 3.2 \mathrm{~mm}$ の 3 種類, ステンレスで沙， $2.0 \mathrm{~mm}$ を標準厚として製 作しています。一般に低圧，中压，高压にわ けた場合，プレートコイルは中压なでの使用 の範团で

$$
\begin{aligned}
& \text { 低生 } \cdots \cdots 2 \sim 5 \mathrm{~kg} / \mathrm{cm}^{2} \\
& \text { 中王 } \cdots \cdots 6 \sim 13 \mathrm{~kg} / \mathrm{cm}^{2}
\end{aligned}
$$

それ以上の高压沉结向きなん（表 1 ）。

\section{5. プレートコイルの形状}

タンクの液のなかに浸せきして，加温又は

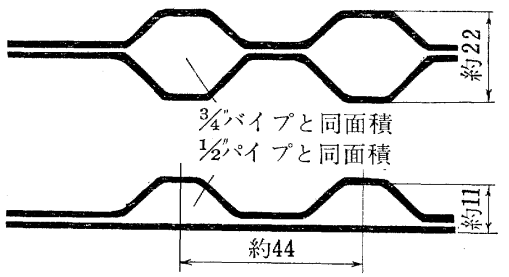

図2プレートコイルの形状断面
冷却する場合は伝熱面積を多くするために 『ダブル形』が使用されます。伝熱面積が多 少減少しても使用目的によって板の片側が平 板になっている，いわゆる『シングル形』も

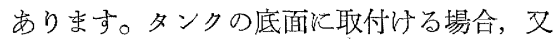
はプレートコイル自身でタンクを製作する場 合には，この『シングル形』が多く使われま 于(図 2)。

\section{6. その他の特徵}

一般に, 蛇管タイプの熱交換器にくらべ板 厚が薄いことによる強度面の心配が考方られ ますが，パス（通路）ごとにシーム溶接を施 エしていますのでそれ自体が補強材の役目を 果たし，特にプレートコイルでタンクを製作 する場合，普通なら $8 \mathrm{~mm}$ 厚の板厚を必要之 する場合，約半分にあたる $4 \mathrm{~mm}$ 『シング ル形のプレートコイル』で充分強度的に酎兄 ることが実証されていすす。

また，『ダブル形』のプレートコイルの断面 積が $3 / 4 "$ ガス管相当径であり，『シングル形』 が $1 / 2$ "ガス管相当径の断面積で温度管理に必 要な流速，流量が適確に得られることるプレ ートユイルの特徴といえます。
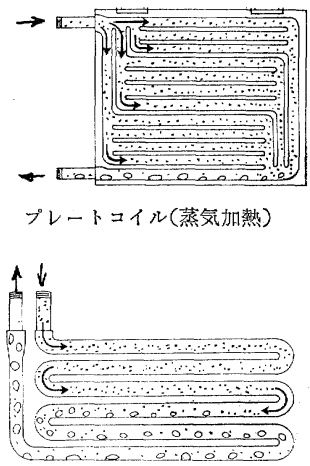

蛇管式 (蒸気加熱)

図 3 


\section{7. なぜプレートコイルがパイプ式 熱交換器にくらべ効率が良いか}

イ、板厚が薄いこと。（設計圧力に耐觉る 厚みの最少板厚を使っている。）

ロ、熱源の吸収率を良くするパス（通路） を作っていること。（図3を見れば，その効 率の良さがわかる。）

八，制約されたスペースのなかに出来るだ け多くの伝熱面積がとれること。（プレー トニイルはダブル形で幅約 $25 \mathrm{~mm}$ 以内。) 二. 断面積が小さいこと。 ホ、熱㥀角に直進する性質があるので, パイプ式のように上部への対流のみでなく タンク内に効率の良い対流を促進させる。

\begin{tabular}{|c|c|}
\hline \multicolumn{2}{|c|}{ テ ス 卜 仕 様 } \\
\hline タンク型格 & $550 \times 1650 \times 900$ \\
\hline & $50^{m} m$ 保温 \\
\hline 正味容量 & $730 l$ (水) \\
\hline 源 & $1,5 \mathrm{~kg} / \mathrm{cm}^{2}$ 蒸気 \\
\hline
\end{tabular}

\begin{tabular}{|c|c|c|}
\hline 項 目 & プレートコイル & 蛇 管 \\
\hline 型 式 & $90 \mathrm{D} \quad 22^{\prime \prime} \times 47^{\prime \prime}$ & $11 / 2 " G P$ \\
\hline 伝熱面積 & $1,64 \mathrm{~m}^{2}$ & $1,65 \mathrm{~m}^{2}$ \\
\hline 量 & $18 \mathrm{~kg}$ & $38 \mathrm{~kg}$ \\
\hline スペース & $\begin{array}{l}20^{m / m} \\
\quad \text { † } 550 \times 1190\end{array}$ & $\begin{array}{l}50^{m / m} \\
\dagger^{m} 680 \times 1100\end{array}$ \\
\hline
\end{tabular}

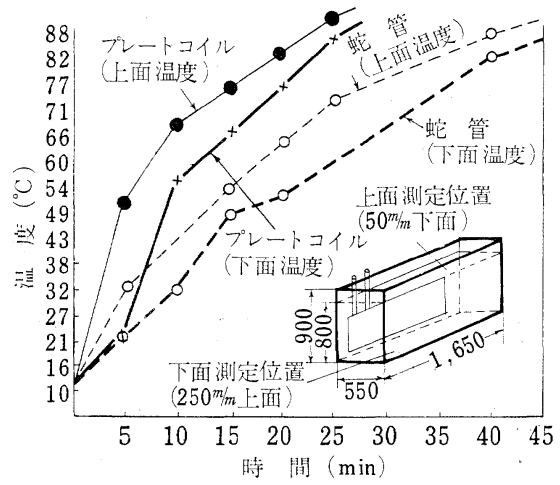

図4 蛇管タイプとプレートコイルの 実測比較値
従って，これらの理由により，ヒートアッ プの時間の短縮と, 熱源の消費量の節減が大 きく現われ，製造原価のコスト低滅に寄与乙 ています。

図 4 は従来の蛇管タイプとプレートコイル を表浾すように同一条件でテストした実測 值をあらわしたもので，例えばタンク上面温 度をとートアップ20分後で比較しますと，

$$
\begin{array}{ll}
\text { プレートニイル } & 83^{\circ} \mathrm{C} \\
\text { 蛇管 (パイプ) } & 65^{\circ} \mathrm{C}
\end{array}
$$

であり，大きく温度差がでています。また， $80^{\circ} \mathrm{C}$ までの加温時間で比較しますと，

$$
\begin{array}{ll}
\text { プレートコイル } & 19 \mathrm{~min} \\
\text { 蛇管 (パイプ) } & 33 \mathrm{~min}
\end{array}
$$

で，これに伴う作業開始時間を考光合せると 大きなメリットがでるはずです。

な抒，図５はプレートコイルと蛇管とのい わゆる“U”值の比較図ですが，この図を見て わかるように, 長さ $126 \mathrm{~cm}$ 前後では两者共 同じ値を示していますが，そ礼より短かい場 合, 或いは長い場合では, 明らかにプレート コイルの注らが優れていることがわかりま す。従って, 効率面からいらと短かいるのを 必要伝熱面積ぶんだけ集めた汴らが，長いる のを数少なく使用するよりす良いということ がい总す。しかし，イニシアルコスト面で は，前者の核うが割高仙なことは事実です から，ランニングコストか，イニシアルコス

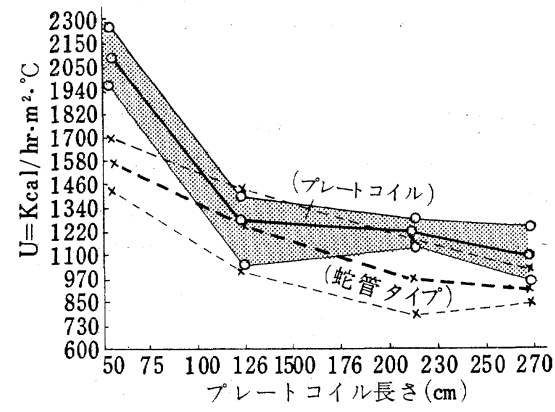

図 5 マルチタイプと蛇管タイプの 熱貫流係数 “U”比較 
表 2 熱貫流係数 $\mathrm{U}=\mathrm{Kcal} / \mathrm{hr} . \mathrm{m}^{2 \circ} \mathrm{C}$

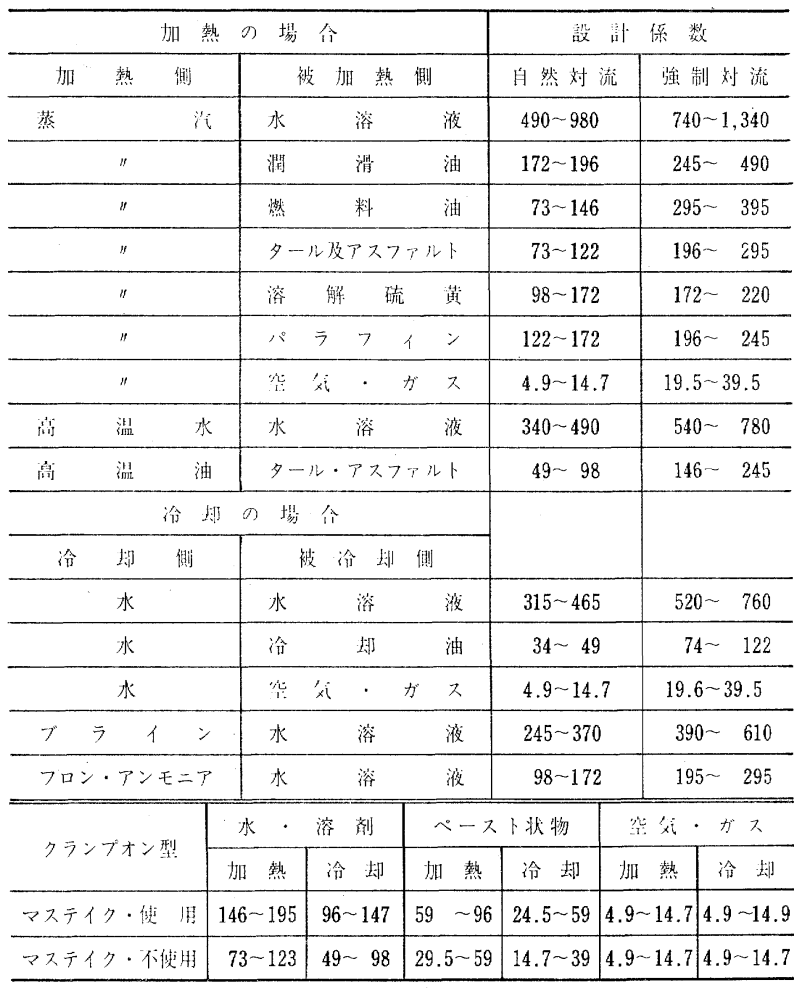

場合, プレートコイルをタ ンク型状に合わせ加工し, 熱効果を良くするために, 伝熱セメント（マスティッ ク）をあらかじめプレート コイル内部に塗布し,タン クに取付ける方法をいいま す。これは材質面の影響す なく，現在あらゆる業界に 相当数使用されてい柰。

\section{9. プレートコイル}

\section{Suction Heater}

ご承知のように，粘質性 りものの加熱心"U”值も悪 く, 余程の強制対流をさせ ないと加熱は困難ですが， この場合いわゆる『槽外加 熱』の専用として製作した のがこの Suction Heater です。タンクの内部にスペ 一スがない場合や通常のか

トか，いずれを主体に考兄るがよって判断 すべきでしょう。

\section{8. プレートコイルの使用別 熱貫流係数"U"值の実績表}

表 2 は加熱, 冷却の場合の使用条件による 実績表を示したものです。数值に幅があるの は, 板厚, 材質などの要因を総合して表わし てあるためで, 従来のパイプ式の熱交換器と 此較すれば参考になると思います。

な持, クランプオン型というのは, 例觉ば, タンクの内部がゴムライニング，グラスライ ニングなど, 外部から溶接ができない場合, 又は、タンク内部に熱交換器を設置できない
くはん機が使用できない場合などに循環ポン プを使用して強制的に対流を起こして熱交換 を行なわせる方法として利用するあのです。 熱量計算迀必要伝熱面積を算出し, 必要 な寸法のプレートコイルをバンクに組んだも のを円筒に組込多ます。

\section{0. 特殊な利用方法}

円筒タンクのかくはん効果をより一層有効 ならしめるためには, タンク壁面にバッフル を取付けることは常識になっていますが，プ レートコイルは熱交換器とバッフルの役目を 同時以満足させます。図6 は加熱特よび冷却 用の熱交換器として同時にかくはん効果を良 
くするためバッフルとして 利用したものです。

また，図７はプレートコ イルのシングル形で直接タ ンクを製作したベッセルタ ンクを示しています。従来 のような二重金（ジャケッ ト）より板厚を薄くするこ とができ，製作費の低減と 熱効率の向上成果をあげ ています。某製鉄所で排液 の温度を利用し冷却水で排

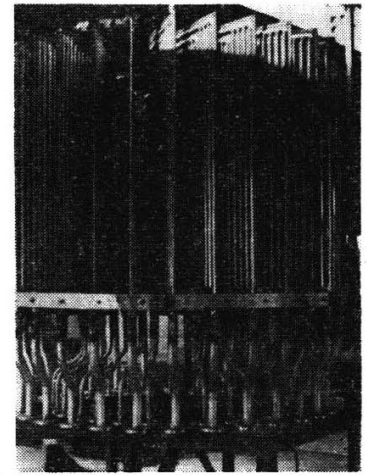

図6 加熱及び冷却用熟交換器

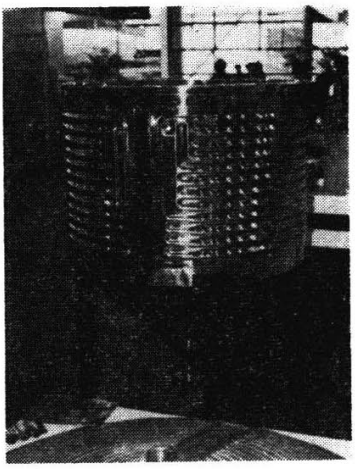

図7ベッセルタンク 液を冷却すると同時に, 冷水を温水熱交換 し，その温水をボイラーに使用することによ り蒸気の低減額が月当り約百万円になったも のです。この場合, 1 基約 $80 \mathrm{~m}^{2}$ で通常のガ 不管を使用する場合, この面積に相当するス ペースは大体 2 倍を必要とします。

\section{1. スラッジ除去方法}

金属表面処理加熱槽用の熱交換器で問題に なるのは, なんといってもスラッジの付着で す。一般的な除去法については省略します が, プレートコイルを使用した場合, 图8 K 示すように，蒸気配管と同じ大ささの冷水配 管をして 4 個のバルブを取付け, 加工液が高 温のときに，まず蒸気のとおるバルブを締め て冷水を約 30 秒通します。次冷水のバルブ を締めてから蒸気を30秒と扎しす。これを 5 回繰り返すと大部分のスケールがはく落し ます。

[実施例] $2,000 l$, リ酸塩皮膜化成処理槽 プレートコイル $1.7 \mathrm{~m}^{2}$ (伝熱面積)， 1 週間後 飞処理を行ない，1回の冷水通過で約 $4 \mathrm{~kg}$ の スケール除去, そのときの総スケール量の 40 \%，5回絽り返すことにより90\%の除去がで きた。

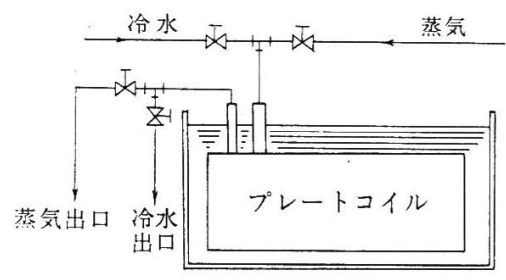

図8金属表面処理加熱槽用プレート コイルのスケール除去法

\section{2. あとがき}

本題が表面処理業界を対称にしていますの で, プレートコイルもその範囲にとどめます が, 他の業界では非常に多種類にわたり利用 されてい委す。現在, 米国の表面処理業界で は当社の技術提携先のトランター社の調査に よれば，蛇管タイプは殆んど使用しておら ず, 板状の熱交換器, 特にプレートコイルが その大半を占めて扣ります。な括，蒸気の消 費量も同一伝熱面積の蛇管タイプとくらべ, 約30\%の低減ができた A 社, また，ヒートア ップの時閒が $40 \%$ も短縮できた $\mathrm{S}$ 社など, 少 しでもエネルギーの節減に協力すべく一層の 努力をして赫ります。 